\title{
СОЦАЛЬНИЙ РОЗВИТОК ДІТЕЙ МОЛОДШОГО ШКІЛЬНОГО ВІКУ 3 АУТИЗМОМ 3 ОПОРОЮ НА МЕТОДИ $З$ НАУКОВО ДОВЕДЕНОЮ ЕФЕКТИВНІСТЮ
}

\author{
Скрипник T. B. \\ професор кафедри спечіальної та інклюзивної освіти \\ Київський університет імені Бориса Грінченка \\ вул. Маршала Тимошенка, 13Б, Київ, Україна \\ orcid.org/0000-0002-8511-4984 \\ t.skrypnyk@kubg.edu.ua
}

Супрун Г. В.

старший викладач кафедри спеціальної та інклюзивної освіти

Київський університет імені Бориса Грінченка

вул. Маршала Тимоченка, 13Б, Киї, Україна

orcid.org/0000-0003-3282-7603

h.suprun@kubg.edu.ua

\author{
Максимчук М. 0. \\ старший викладач кафедри спеціальної та інклюзивної освіти \\ Київський університет імені Бориса Грінченка \\ вул. Маршала Тимошенка, 13Б, Київ, Україна \\ orcid.org/0000-0003-1834-6897 \\ m.maksymchuk@kubg.edu.ua
}

\begin{abstract}
Ключові слова: аутизм, учні з аутизмом, соиіальний розвиток, методи з науково доведеною ефективністю.
\end{abstract}

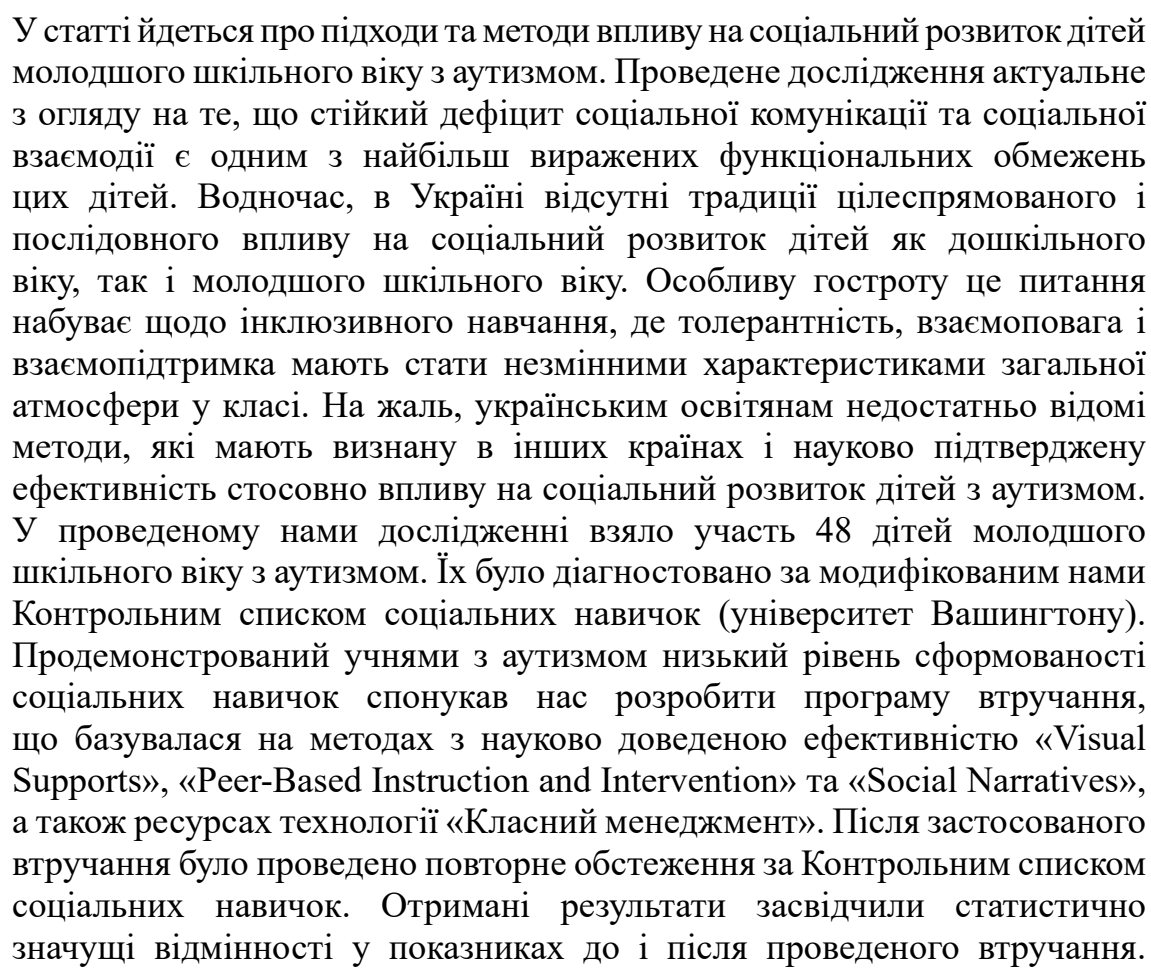


3'ясовано, що найбільше зростання отримано за показниками «Поведінка на початку гри», «Проміжна/перехідна ігрова діяльність» та «Розуміння емоцій». Визначено умови для позитивних змін стосовно емоційної саморегуляції дітей 3 аутизмом та оволодіння навичками взаємодії у класному колективі. Серед цих умов: більш злагоджена співпраця учасників команди супроводу; більш тривалий час для втручання; облік додаткових потреб певних учнів 3 РАС, що передбачає застосування додаткових методів 3 науково доведеною ефективністю.

\title{
SOCIAL DEVELOPMENT OF CHILDREN OF PRIMARY SCHOOL AGE WITH AUTISM RELYING ON EVIDENCE BASED PRACTICE
}

\author{
Skrypnyk T. V. \\ Professor at the Department of Special and Inclusive Education \\ Borys Grinchenko Kyiv University \\ Marshala Tymoshenko str., 13B, Kyiv, Ukraine \\ orcid.org/0000-0002-8511-4984 \\ t.skrypnyk@kubg.edu.ua \\ Suprun H. V. \\ Senior Lecturer at the Department of Special and Inclusive Education \\ Borys Grinchenko Kyiv University \\ Marshala Tymoshenko str., 13B, Kyiv, Ukraine \\ orcid.org/0000-0003-3282-7603 \\ h.suprun@kubg.edu.ua \\ Maksymchuk M. O. \\ Senior Lecturer at the Department of Special and Inclusive Education \\ Borys Grinchenko Kyiv University \\ Marshala Tymoshenko str., 13B, Kyiv, Ukraine \\ orcid.org/0000-0003-1834-6897 \\ m.maksymchuk@kubg.edu.ua
}

Key words: autism, students with autism, social development, evidence based practice.
The article focuses on the approaches and methods of social sphere development in primary school children with autism. The study is relevant given that the persistent deficit of social communication and social interaction is one of the most important functional limitations of these children. At the same time, there are no traditions of purposeful and consistent influence on the social development of children of both preschool and primary school age in Ukraine. This issue is particularly acute in inclusive education, where tolerance, mutual respect and mutual support should become core characteristics of the general atmosphere in class. Unfortunately, Ukrainian educators are not sufficiently aware of those methods that in other countries are recognized and scientifically proven to be effective in influencing the social development of children with autism. The current study involved 48 primary school children with autism. They were assessed with the Social Skills Checklist (University of Washington) modified by us for the study. The study revealed the low level of social skills development among primary school children with autism. Thus, an intervention program built on such evidence-based methods as "Visual Supports", "Peer-Based Instruction and Intervention" and "Social Narratives", as well as resources of "Classroom Management" technology was designed. 
The obtained results showed statistically significant differences in Social Skills Checklist indicators before and after the intervention program. It was found that largest increase was obtained across such domains as "Behavior at the Beginning of a Game", "Transitional Game Activity" and "Understanding of Emotions". The conditions for positive changes in emotional self-management development, as well as interaction skills development in children with autism are determined in the study. Among these conditions: more coordinated cooperation of the members of IEP teams; longer time for intervention; taking into account the additional needs of certain students with ASD, which provides for the use of additional methods with evidence based practice.

Постановка проблеми. Серед функціональних обмежень дітей з розладами аутистичного спектра (РАС) одним із найбільш виражених $є$ стійкий дефіцит соціальної комунікації та соціальної взаємодії. Серед характеристик дітей цієї групи вирізняють: брак реагування на звернення, прохання і пропозиції інших людей; нездатність грати 3 іншими дітьми, орієнтуватися на них, зважати на них, виявляти соціальні навички (вітатися, прощатися, вибачатися, просити те, що хочеш); неспроможність розпочинати соціальну взаємодію; розвивати ті чи інші стосунки; розуміти контекст ситуації і власну соціальну роль у них.

Недостатнє розуміння дітьми 3 РАС правил взаємодії, а також відсутність цілеспрямованого оволодіння ними соціальними навичками негативно позначається на процесі їхньої соціальної адаптації та ускладнює їхній подальший розвиток і соціалізацію. У цілому, можна зазначити: дитина 3 аутизмом зі значними труднощами переймає досвід соціального життя, засвоює правила та норми поведінки.

Незважаючи на те, що міжнародна спільнота на регулярній основі у закладах освіти впроваджує соціально-емоційне навчання (social-emotional learning, SEL), в Україні подібні програми відсутні. Заплановані класним керівником виховні години, навіть присвячені важливим соціальним питанням (взаємовідносини, керування своїми емоціями, співчуття іншим тощо), є несистематичними і непослідовними.

Проведені дослідження $[1 ; 2]$ засвідчили недостатній рівень здатності українських педагогів створювати відповідне інклюзивне освітнє середовище, що має набувати ознак поваги до різноманіття та нагальну потребу у підвищенні компетентності педагогів щодо цілеспрямованого емоційного розвитку школярів.

Якщо йдеться про клас 3 інклюзивною формою навчання, то вміння налагоджувати сприятливу для навчання і розвитку усіх дітей атмосферу постає особливо гостро. Коли ж серед учнів 3'являються діти з РАС, то потреба у спеціальних заходах щодо створення продуктивної взає- модії набуває особливого звучання, адже ці діти не зважають на інших людей і не наслідують їх. Тому оволодіння методами соціального розвитку дітей з РАС дасть змогу педагогам закладу освіти здійснювати успішну підтримку учасниками міждисциплінарної команди супроводу, а також налагоджувати ефективну взаємодію у класному колективі.

Аналіз останніх досліджень та публікацій. Розуміючи значущість соціального розвитку дітей з РАС, у цілому, у цій статті нам хотілося б конкретизувати необхідність розвитку як соціальної, так й емоційної компетентності. На наше переконання, уміння розпізнавати, розуміти $\mathrm{i}$ керувати емоціями (те, що узагальнено охоплено терміном «емоційний інтелект») - це важливі уміння у контексті міжособистісного спілкування й соціальної взаємодії, тобто - соціальної сфери. Дослідження останніх десятиліть гостро піднімають тему щодо ролі соціальних якостей та емоційного інтелекту не тільки у плані соціалізації особистості, але й у плані оволодіння академічними навичками на всіх етапах освітнього процесу (початкова та старша школа).

Так, польська науковець D. Al-Khamisy y своєму дослідженні визначає, що діалогова модель співпраці (з опорою на здатність до командної взаємодії як показник емоційного інтелекту) уможливлює запобігання розвитку дислексії [3]. Португальські науковці доводять позитивний вплив емоційного інтелекту на самоефективність учнів та їхні академічні досягнення [4]. Група іспанських дослідників [5] здійснила метааналіз взаємозв'язку емоційного інтелекту та академічної успішності за 44 публікаціями (2017-2020 роки). У межах цього дослідження виявлено достатній зв'язок між емоційним інтелектом та академічними досягненнями; при цьому, основний акцент робиться на тому, що для успішності в навчальній діяльності велике значення мають такі складники емоційного інтелекту і соціального розвитку, як: адаптивні можливості, самоідентичність, емоційна саморегуляція та навички міжособистісного спілкування. Американські науковці доводять роль соціальних 
навичок як чинника покращення в осіб з особливими освітніми потребами соціального пізнання, соціальних функцій та соціальної впевненості, а також зниження тривожності та тенденції до зменшення симптомів депресії [6].

Загальновизнаним $є$ той факт, що у дітей з РАC відсутні сформовані соціальні якості, але іншим чином (ситуативно і непослідовно) виявляються ті самі потреби соціального плану, як і в інших дітей: базова потреба у безпеці, потреба у приналежності та любові, потреба у соціальних зв'язках та ін. При цьому доведено, що молодший шкільний вік є сприятливим періодом для формування соціально-емоційних навичок [7].

У вітчизняних дослідженнях: розкрито суттєву роль соціальних навичок в особистісному зростанні школяра в контексті нової української школи, що передбачає відповідну компетентність вчителя щодо створення атмосфери емоційного комфорту, партнерські взаємини між школярами, вчителями й батьками [8]; встановлено зв'язок між емоційним інтелектом у дітей молодшого шкільного віку з такими поняттями, як соціалізація, комунікативність, адаптація, а також його вплив на підвищення академічної успішності учнів початкових класів [9]. 3'ясовано також, що формування у молодших школярів емоційного інтелекту як комплексу наскрізних умінь потребує спеціальної підготовки вчителя та цілеспрямованої системної роботи з розвитку емоційного інтелекту молодших школярів [10]. У нашому попередньому дослідженні представлено технологічний аспект формування соціально-емоційних компетенцій в учнів інклюзивних класів 3 опорою на Нову модель емоційного інтелекту A. S. Drigas та C. Papoutsi [1].

Незважаючи на те, що в українських наукових джерелах наявні дослідження, присвячені розвитку соціальних навичок та емоційного інтелекту у школярів, при цьому вкрай недостатньо навчально-методичних розробок, завдяки яким можна було б значно посилити педагогічну майстерність фахівців у формуванні соціальних навичок в учасників інклюзивного навчання, у цілому, та у дітей з РАС, зокрема.

Мета статті - систематизувати підходи та методи формування соціальних навичок в учнів початкових класів 3 аутизмом, а також перевірити стан їхньої соціального розвитку після проведеного втручання 3 опорою на методи 3 науково доведеною ефективністю.

Виклад основного матеріалу дослідження. Застосування ефективних втручань щодо соціального розвитку дітей з РАС має важливе значення у контексті реалізації їхнього потенціалу та повноцінної участі у життєдіяльності. Особливо важливими серед них $є$ ті, які заслуговують визнання практиків, а також ті, що мають науково доведену ефективність.

Проведений педагогічний експеримент [2], спрямований на оволодіння педагогами технологією формування емоційного інтелекту учнів 3 особливими освітніми потребами, засвідчив позитивні зміни як у плані соціально-емоційного розвитку учнів, так і у їхніх досягненнях у навчальній діяльності. Отримані зрушення у майстерності педагогів завдяки послідовно організованому навчанню спонукали нас продовжити дослідницько-експертну діяльність у цьому напрямі. Міжнародними дослідженнями також підтверджено, що розвиток соціальних якостей учнів багато у чому залежить від стану сформованості цих якостей у педагогів, власне, від змісту і спрямованості педагогічної практики $[11 ; 12 ; 13]$.

Новий ракурс нашого дослідження полягав у визначенні підходів та методів цілеспрямованого соціального розвитку учнів інклюзивних класів з РАС.

У діагностичній частині ми спиралися на напрацювання співробітників вашингтонського університету, які у межах проєкту «DATA» (Developmentally Appropriate Treatment for Autism) розробили Контрольний список соціальних навичок [14]. Впроваджений у проєктній діяльності підхід передбачав об'єднання дітей 3 PAC 3 дітьми, які мають типовий розвиток, щоб вони мали здатність практикувати і розвивати соціальні навички в природних умовах, при цьому контрольний список соціальних навичок давав змогу тримати у фокусі уваги потрібні орієнтири та здійснювати моніторинг динаміки розвитку дітей. Наявний «Контрольний список соціальних навичок» було нами модифіковано до завдань нашого дослідження, в наслідок чого ми виокремили три шкали: 1) соціальна гра та емоційний розвиток; 2) емоційна регуляція; 3) навички групової взаємодії.

За модифікованим «Контрольним списком» було обстежено 48 дітей молодшого шкільного віку з РАС від 7 до 12 років. Дослідження здійснювалося за письмовою згодою батьків; бланки заповнювали педагоги разом 3 батьками. Рейтингова шкала передбачала оцінювання за часовими показниками: майже завжди (4 бали); часто (3 бали), інколи (2 бали) та майже ніколи (1 бал). Отриманий частотний розподіл показників представлено у таблиці (табл. 1)

За показниками, представленими у таблиці, можна дійти висновку, що за станом сформованості усіх соціальних навичок переважають оцінки «Майже ніколи» та «Іноді», при цьому стосовно 6 параметрів оцінка «Майже завжди» відсутня, а два інші параметри мають незначні відсотки за цією оцінкою. Таким чином, здійснене дослі- 
Таблиця 1

Частотний розподіл показників за шкалами «Контрольного списку» до впровадження програми втручання

\begin{tabular}{|c|c|c|c|c|c|}
\hline \multirow{2}{*}{\multicolumn{2}{|c|}{ Шкали опитувальника }} & \multicolumn{4}{|c|}{ Відсоток (\%) } \\
\hline & & \multirow{2}{*}{$\begin{array}{c}\text { Майже } \\
\text { ніколи }\end{array}$} & \multirow{2}{*}{$\begin{array}{c}\text { Іноді } \\
47,9 \\
\end{array}$} & \multirow{2}{*}{$\begin{array}{c}\text { Часто } \\
33,3 \\
\end{array}$} & \multirow{2}{*}{$\begin{array}{c}\text { Майже } \\
\text { завжди } \\
6,3 \\
\end{array}$} \\
\hline Соціальна & Поведінка на початку гри & & & & \\
\hline $\begin{array}{l}\text { гра та емоційний } \\
\text { розвиток }\end{array}$ & Проміжна /перехідна ігрова діяльність & 58,3 & 31,3 & 10,4 & 0 \\
\hline \multirow[t]{3}{*}{ Емоційна регуляція } & Розуміння емоцій & 45,8 & 41,7 & 12,5 & 0 \\
\hline & Саморегуляція & 33,3 & 52,1 & 14,6 & 0 \\
\hline & Гнучкість & 66,7 & 33,3 & 0 & 0 \\
\hline \multirow{3}{*}{$\begin{array}{l}\text { Навички } \\
\text { взаємодії в групі }\end{array}$} & Звернення по допомогу & 68,8 & 31,3 & 0 & 0 \\
\hline & Слідує/бере участь у житті групи & 52,1 & 39,6 & 8,3 & 0 \\
\hline & Участь у груповій діяльності & 27,1 & 41,7 & 27,1 & 4,2 \\
\hline
\end{tabular}

дження виявило критично недостатню сформованість соціальних навичок у дітей молодшого шкільного віку з РАС.

Для впровадження цілеспрямованого втручання 3 метою підвищення рівня сформованості соціальних навичок у дітей з РАС ми обрали такі методи $з$ науково доведеною ефективністю, як «Visual Supports», «Peer-Based Instruction and Intervention» та «Social Narratives» [15], a також візуальні засоби 3 технології «Класний менеджмент».

Застосування методу «Visual Supports» («Вiзуальна підтримка») дало нам змогу налагодити процес структурування простору, часу i діяльності. В освітньому просторі було впроваджено: a) символічне та кольорове позначення зон (навчання, сенсорне розвантаження, гра-спілкування); б) візуальний розклад дня (заняття, перерва, вільній час, харчування, додаткові заняття/ активності); в) правила поведінки, які учасники команди супроводу узгоджено застосовували під час взаємодії з тією чи іншою дитиною з РАС на уроках, заняттях, у період дозвілля, а батьки - в соціально-побутових умовах.

Метод «Peer-Based Instruction and Intervention» («Навчання та втручання, опосередковане однолітками») у нашому дослідженні передбачав сплановані види взаємодії дітей з РАС та їхніх однокласників за умови: 1) попередньої підготовки однокласників (навчання здатності бачити сильні сторони у дитини з РАС, умінню привертати іï увагу, надавати продуктивну допомогу, вчити їі тому, як разом навчатися і грати тощо); 2) відпрацювання різних методів такого втручання «Модель», «Помічник», «Похвала і заохочення»: 3 ) долучення до процесу втручання різних однолітків.

Впровадження методу «Social Narratives» («Соціальні історії») полягало у розробці та використанні серії соціальних історій, розроблених індивідуально для кожної дитини з урахуванням актуальних цілей ii розвитку, стосовно тих ситуацій, які викликали у неї найбільші труднощі, наприклад: повідомити про фізіологічні потреби, попросити про допомогу вчителя під час уроку, повідомити про погане самопочуття, запитати в іншої дитини дозволу погратись іiі іграшкою, запросити до гри однолітка.

Використання ресурсів технології «Класний менеджмент» дали змогу створити привабливе, підтримувальне, розвивальне середовище для усіх учнів інклюзивного класу та сприяти їхньому соціальному розвитку. У цьому напрямі впливу ми використовували ідеї, які було систематизовано у попередньому науковому дослідженні (візуалізовані правила та процедури; спектр емоцій та техніки для самозаспокоєння на картках; дошка «Зірка класу», «Емоційний термометр»; кутки учнів та педагога; креативна дошка класних обов'язків) [1]. Ці ресурси «Класного менеджменту» педагоги задіювали, щоб надавати можливість кожному учню виконувати значущі ролі, створювати ситуації для розвитку таких соціальних навичок, як: активне слухання, виявлення цікавості до іншого, здатність розділяти радість та сум, уміння цінувати внесок кожного у спільну справу, вміння спільно приймати рішення.

Проведена оцінка стану сформованості соціальних навичок після проведеного дослідження показала суттєві відмінності у порівнянні з попередніми показниками. Відмінності представлено нами за параметром «середній бал» та за Т-критерієм Ст'юдента (табл. 2).

Аналіз результатів статистичної обробки даних, представлених у таблиці 2, свідчить про те, що наявні статистично значущі відмінності у показниках між ДО і ПІСЛЯ втручання $(\mathrm{p}<0,001)$. При цьому визначено, що найбільшу різницю середніх мають перші три параметри, отже саме у «Поведінці на початку гри», «Проміжній /перехідній ігровій діяльності» та «Розумінні емоцій» помітне найбільше зростання 
Таблиця 2

Порівняння середнього балу за шкалами «Контрольного списку» за Т-критерісм Ст'юдента до та після впровадження програми втручання

\begin{tabular}{|c|c|c|c|c|c|c|}
\hline \multicolumn{2}{|c|}{$\begin{array}{c}\text { Шкали опитувальника } \\
\text { та їх параметри }\end{array}$} & \multirow{2}{*}{$\begin{array}{c}\text { Середнс } \\
\text { значення } \\
\text { ДО } \\
2,3 \\
\end{array}$} & \multirow{2}{*}{$\begin{array}{c}\begin{array}{c}\text { Середнс } \\
\text { значення } \\
\text { ПІСЛЯ }\end{array} \\
3,4 \\
\end{array}$} & \multirow{2}{*}{$\begin{array}{c}\begin{array}{c}\text { Різниця } \\
\text { середніх } \\
\text { значень }\end{array} \\
-1,1 \\
\end{array}$} & \multirow{2}{*}{$\begin{array}{c}\text { T-критерій } \\
\text { Ст'юдента } \\
-10,566 \\
\end{array}$} & \multirow{2}{*}{$\begin{array}{c}\begin{array}{c}\text { Рівень } \\
\text { значимості }\end{array} \\
0,000 \\
\end{array}$} \\
\hline 1. Соціальна гра & Поведінка на початку гри & & & & & \\
\hline $\begin{array}{l}\text { та емоційний } \\
\text { розвиток }\end{array}$ & $\begin{array}{l}\text { Проміжна /перехідна } \\
\text { ігрова діяльність }\end{array}$ & 1,5 & 2,5 & $-1,0$ & $-12,401$ & 0,000 \\
\hline \multirow{3}{*}{$\begin{array}{l}\text { 2. Емоційна } \\
\text { регуляція }\end{array}$} & Розуміння емоцій & 1,7 & 2,7 & $-1,0$ & $-12,528$ & 0,000 \\
\hline & Саморегуляція & 1,8 & 2,6 & $-0,8$ & $-8,883$ & 0,000 \\
\hline & Гнучкість & 1,3 & 2,1 & $-0,8$ & $-7,722$ & 0,000 \\
\hline \multirow{3}{*}{$\begin{array}{l}\text { 3. Навички } \\
\text { взаємодії в групі }\end{array}$} & Звернення по допомогу & 1,3 & 2,0 & $-0,7$ & $-7,742$ & 0,000 \\
\hline & $\begin{array}{l}\text { Слідує/бере участь } \\
\text { у житті групи }\end{array}$ & 1,6 & 2,4 & $-0,8$ & $-10,149$ & 0,000 \\
\hline & $\begin{array}{l}\text { Участь у груповій } \\
\text { діяльності }\end{array}$ & 2,1 & 3 & $-0,9$ & $-10,007$ & 0,000 \\
\hline
\end{tabular}

показників у дітей з аутизмом після проведення програми втручання.

Що стосується інших параметрів, то нами узагальнено умови їх становлення у дітей з РАС: більш узгоджена співпраця фахівців між собою та фахівців з батьками цих дітей, щоб набуті уміння відпрацьовувалися в умовах життєдіяльності за межами закладу освіти; більш тривалий час для втручання; урахування додаткових потреб певних учнів з РАС у нормалізації стану, активізації комунікативної діяльності, що передбачає застосування додаткових методів 3 науково доведеною ефективністю (наприклад, «Альтернативна та допоміжна комунікація», «Сенсорна інтеграція ®» та ін.).

Висновки. Проведене нами дослідження дало змогу 3'ясувати суттєву потребу в навчально-методичному забезпеченні процесу втручання щодо становлення у дітей молодшого віку з РАС соціальних навичок. Відсутність традицій в українській освітянській спільноті щодо цілеспрямованого й послідовного формування у дітей, у цілому, і у дітей 3 аутизмом, зокрема, соціальних яко- стей спонукало нас до пошуку й систематизації ефективних підходів і методів, що застосовують учасники команд супроводу дітей з РАC 3 інших країн у своїй успішній практиці. Розроблена нами система втручання, що охоплювала методи 3 науково доведеною ефективністю («Visual Supports», «Peer-Based Instruction and Intervention», «Social Narratives») та візуальні засоби 3 технології «Класний менеджмент», виявила значну позитивну динаміку в формуванні соціальних навичок у дітей молодшого шкільного віку з РАС. Це було підтверджено порівняльним аналізом середнього балу за методикою «Контрольний список соціальних навичок», що використано для обстеження цих дітей до початку процесу втручання та після цього процесу, а також - за Т-критерієм Ст'юдента. Наші подальші дослідження будуть присвячені визначенню етапності у формуванні соціальних навичок у дітей з РАС та визначенню особливостей їх формування у відповідності до віку та контексту урахування їхньго цілісного розвитку.

\section{ЛІТЕРАТУРА}

1. Skrypnyk T., Martynchuk O., Klopota O., Gudonis V., Voronska N. Supporting of Children with Special Needs in Inclusive Environment by the Teachers Collaboration. Pedagogika. 2020. Vol. 138 (2). P. 193-208.

2. Martynchuk O., Skrypnyk T., Maksymchuk M, Babych N., Biriukova K. Professional readiness of future special education teachers for inclusive education in Ukraine. Society. Integration. Education. Proceedings of the International Scientific Conference. 2021. Vol. III,. P. 159-172.

3. Al-Khamisy D. Supporting the student at risk of dyslexia in school according to the dialogue model. Polish school experiences. International Technology, Education and Development. Conference Proceedings. 2017. 3432-3438.

4. Costa A., Faria L. The impact of emotional intelligence on academic achievement: A longitudinal study in Portuguese secondary school. Learning and Individual Differences. 2015. 37. P. 38-47.

5. Sánchez-Álvarez N., Martos M.-P., Extremera N. (2020) A Meta-Analysis of the Relationship Between Emotional Intelligence and Academic Performance in Secondary Education: A Multi-Stream Comparison. Frontiers in Psychology. 2020. 11. P. 1517. 
6. Connor A., Sung C., Strain A., Zeng S. T., Fabrizi S. Building Skills, Confidence, and Wellness: Psychosocial Effects of Soft Skills Training for Young Adults with Autism. Journal of Autism and Developmental Disorders. 2020. 50(6). P. 2064-2076.

7. Garbenis S., Geleziniene R., Siauciulyte G. Development of emotional intelligence in students with special educational needs. Social Welfare Interdisciplinary Approach. 2020. 10(1). P. 106-120.

8. Сухопара I. Чинники розвитку емоційного інтелекту молодших школярів у контексті нової української школи. Науковий вісник МНУ імені В. О. Сухомлинського. Педагогічні Науки. 2019. № 2 (65). C. 296-301.

9. Брославська Г. М., Дригач Т. Г. Розвиток емоційного інтелекту учнів початкових класів. Наукові записки кафедри педагогіки.2020. 47. С. 7-13.

10. Мельник О. М. Розвиток емоційного інтелекту молодших школярів. Педагогіка формування творчої особистості у вищій $і$ загальноосвітній школах. 2020. № 73, Т. 1. С. 128-133.

11. Denervaud S., Mumenthaler C., Gentaz E., Sander D. Emotion recognition development: Preliminary evidence for an effect of school pedagogical practices. Learning and Instruction. 2020. Vol. 69: 101353.

12. Hoffmann J. D., Brackett M. A., Bailey C. S., Willner C. J. Teaching emotion regulation in schools: Translating research into practice with the RULER approach to social and emotional learning. Emotion. 2020. 20 (1). P. 105-109.

13. Tveit H. H., Drugli M. B., Fossum S., Handegård B. H., Stenseng F. Does the Incredible Years Teacher Classroom Management programme improve child-teacher relationships in childcare centres? A 1-year universal intervention in a Norwegian community sample. European Child \& Adolescent Psychiatry. 2020. Vol. 29 (5). P. 625-636.

14. Schwartz I., Sandall S., McBride B. Project DATA (Developmentally Appropriate Treatment for Autism): An Inclusive School-Based Approach to Educating Young Children with Autism. Topics in Early Childhood Special Education. 2004. Vol. 24(3). P. 156-168.

15. Hume K., Steinbrenner J. R., Odom S. L., Morin K. L., Nowell S. W., Tomaszewski B. Evidence-Based Practices for Children, Youth, and Young Adults with Autism: Third Generation Review. Journal of Autism and Developmental Disorders. 2021. 45(7).

\section{REFERENCES}

1. Skrypnyk, T., Martynchuk, O., Klopota, O., Gudonis, V., \& Voronska, N. (2020). Supporting of Children with Special Needs in Inclusive Environment by the Teachers Collaboration. Pedagogika, 138(2), 193-208. doi:10.15823/p.2020.138.11

2. Martynchuk, O., Skrypnyk, T., Maksymchuk, M., Babych, N., \& Biriukova, K. (2021). Professional readiness of future special education teachers for inclusive education in Ukraine. Society. Integration. Education. Proceedings of the International Scientific Conference, 3, 159-172. doi:10.17770/sie2021vol3.6409

3. Al-Khamisy, D. (2017). Supporting the student at risk of dyslexia in school according to the dialogue model. polish school experiences. Paper presented at the 11th International Technology, Education and Development Conference, Valencia, Spain. 6-8 March, 2017. https://www.researchgate.net/ publication/314334818_Supporting_the_student_at_risk_of_dyslexia_in_school_according_to_the_ dialogue_model_Polish_school_experiences

4. Costa, A., \& Faria, L. (2015). The impact of Emotional Intelligence on academic achievement: A longitudinal study in Portuguese secondary school. Learning and Individual Differences, 37, 38-47. doi:10.1016/j.lindif.2014.11.011

5. Sánchez-Álvarez, N., Berrios Martos, M. P., \& Extremera, N. (2020). A Meta-Analysis of the Relationship Between Emotional Intelligence and Academic Performance in Secondary Education: A Multi-Stream Comparison. Frontiers in Psychology, 11, 1517.

6. Connor, A., Sung, C., Strain, A., Zeng, S. T., \& Fabrizi, S. (2020). Building Skills, Confidence, and Wellness: Psychosocial Effects of Soft Skills Training for Young Adults with Autism. Journal of Autism and Developmental Disorders, 50(6), 2064-2076. doi:10.1007/s10803-019-03962-w

7. Garbenis, S., Geleziniene, R., \& Šiaučiulytè, G. (2020). Development of emotional intelligence in students with special educational needs. Social Welfare: Interdisciplinary Approach, 1(10), 106-120. doi:10.21277/ sw.v1i10.525

8. Sukhopara, I. (2019). Chynnyky rozvytku emotsiioho intelektu molodshykh shkoliariv u konteksti novoi ukrainskoi shkoly [Factors of development of emotional intelligence of junior schoolchildren in the context of a new Ukrainian school]. Scientific Visnyk V.O. Sukhomlynskyi Mykolaiv National University. Pedagogical Sciences, 65(2), 296-301. doi:10.33310/2518-7813-2019-65-2-296-301. [In Ukrainian]. 
9. Broslavska, G. M., \& Dryhach, T. G. (2020). Rozvytok emotsiinoho intelektu uchniv pochatkovykh klasiv [Development of emotional intelligence of primary school pupils]. The Scientific Notes of the Pedagogical Department(47), 7-12. doi:10.26565/2074-8167-2020-47-01. [In Ukrainian].

10. Melnyk, O. (2020). Rozvytok emotsiinoho intelektu molodshykh shkoliariv [Development of emotional intellegence of junior school children]. Pedagogy of the formation of a creative person in higher and secondary schools, 1(73), 128-133. doi:10.32840/1992-5786.2020.73-1.24. [In Ukrainian].

11. Denervaud, S., Mumenthaler, C., Gentaz, E., \& Sander, D. (2020). Emotion recognition development: Preliminary evidence for an effect of school pedagogical practices. Learning and Instruction, 69, 101353. doi:10.1016/j.learninstruc.2020.101353

12. Hoffmann, J. D., Brackett, M. A., Bailey, C. S., \& Willner, C. J. (2020). Teaching Emotion Regulation in Schools: Translating Research Into Practice With the RULER Approach to Social and Emotional Learning. Emotion, 20(1), 105-109. doi:10.1037/emo0000649

13. Tveit, H. H., Drugli, M. B., Fossum, S., Handegård, B. H., \& Stenseng, F. (2020). Does the Incredible Years Teacher Classroom Management programme improve child-teacher relationships in childcare centres? A 1-year universal intervention in a Norwegian community sample. European Child \& Adolescent Psychiatry, 29(5), 625-636. doi:10.1007/s00787-019-01387-5

14. Schwartz, I., Sandall, S., McBride, B., \& Boulware, G.-L. (2004). Project DATA (Developmentally Appropriate Treatment for Autism): An Inclusive School-Based Approach to Educating Young Children with Autism. Topics in Early Childhood Special Education, 24(3), 156-168. doi:10.1177/0271121404024 0030301

15. Hume, K., Steinbrenner, J. R., Odom, S. L., Morin, K. L., Nowell, S. W., Tomaszewski, B., Savage, M. N. (2021). Evidence-Based Practices for Children, Youth, and Young Adults with Autism: Third Generation Review. Journal of Autism and Developmental Disorders, 45(7). doi:10.1007/s10803-020-04844-2 